\title{
Protection Orders in the European Member States: Where Do We Stand and Where Do We Go from Here?
}

\author{
Suzan van der Aa
}

Published online: 17 December 2011

C The Author(s) 2011. This article is published with open access at Springerlink.com

\begin{abstract}
This article tries to provide an overview of current criminal, civil and administrative protection order legislation in the 27 European Member States by comparing five studies that have (laterally) touched upon this topic. Although the data are sometimes questionable and, on occasion, even contradictory, the general picture emerges that there is a huge variation in levels of victim protection across the EU. In some Member States there are considerable gaps in victim protection legislation, for example, because there is no (pretrial or post-trial) protection in criminal proceedings or because civil protection orders and/or barring orders are not available. If we agree that in the light of today's emphasis on victim protection the current gaps in protection order legislation can no longer be accepted, a strategy needs to be devised on how to solve this problem. It was argued that the European Union could play an important part in addressing the protective vacuum, first by supporting thorough research into the current status of protection order legislation and implementation in the 27 Member States, and second by further exploring certain 'soft law' possibilities such as co-regulation or the open method of coordination.
\end{abstract}

Keywords Domestic violence · European Member States · Protection order legislation · Stalking

\section{Introduction}

Crime victims who are affected by non-recurrent or incidental crimes, such as a single robbery or assault, are in some respects better off than other victims. Once the incident has taken place, they can file a report with the police, they can sue for damages and, if necessary, they can work on their mental and physical recovery. The incident is clearly limited in time and apart from a possible encounter in court, the victims are generally not confronted with the same offender again.

S. van der Aa $(\bowtie)$

International Victimology Institute Tilburg (INTERVICT), Tilburg University (NL), Warandelaan 2, 5000 LE Tilburg, The Netherlands

e-mail: S.vdrAa@tilburguniversity.edu 
The situation for victims of course-of-conduct crimes, such as stalking or domestic violence, is much more complicated. Due to the offender's obsession with the victim or due to the ongoing violent relationship, the chances of these victims being victimized for a second, third or even tenth time by the same offender are much higher than the chances for the average victim. As long as the violent or harassing incidents keep recurring, victims remain under a constant threat, something which is not conducive to their recovery. In a random community survey, some stalking victims even reported that they would prefer a physical assault over the chronic, psychological nuisance that these repeat offences had brought along (Purcell et al. 2005). ${ }^{1}$

All in all, it is clear that the victims of course-of-conduct crimes by the same offender show an additional need for protection against recidivism. In fact, research findings indicate that one of women's primary concerns in seeking legal intervention is protection for themselves and their children (Stubbs 2008; Johnson et al. 2008). From the 1970s onward, some countries therefore started to enact legislation authorizing protection orders independent of divorce proceedings, often as part of drastic changes in their domestic violence policy. $^{2}$ Another reaction was to reinterpret pre-existing orders so as to apply them to domestic violence and later on to stalking as well. ${ }^{3}$ The problem is that this trend has not spread evenly across the world. Some countries are clearly at the forefront when it comes to victim protection through protection orders, whereas others are still lagging behind.

Recently, the attention for protection orders in the European Member States has been given a new impetus thanks to the initiative for a Directive of the European parliament and the Council on the European Protection Order (hereafter: EPO). ${ }^{4}$ Supposedly, all European Member States have (criminal) protection orders available, ${ }^{5}$ but at present they are only effective on the territory of the state which adopted them, thereby seriously impeding victims who wish to cross borders. Once implemented, the EPO would provide a legal basis for EU Member States to recognize a victim protection order that was granted in another Member State.

The initiative proposal of the EPO seemed to depart from the assumption that, despite the differences in protection order legislation, the Member States were at least able to provide victims with the same level of protection. ${ }^{6}$ Although this assumption seems to have been retracted in the European Parliament's position, ${ }^{7}$ it nevertheless raises an interesting

\footnotetext{
${ }^{1}$ Purcell et al. (2005) conclude that the fear and menace associated with threats may be more emotionally damaging to victims than the reality of physical harm.

${ }^{2}$ This was the case in, for example, the United States. Currently, every state and the District of Columbia has a protection order statute in place (Sack 2004; Smith 2005).

3 In the Netherlands, for example, some women's shelters already used the provisional civil protection order as a means to keep the abusive (ex)partner away from the victim, but it was only after a publicity campaign by feminist lawyers in the early 1980 s that the civil protection order became popular as a strategic means for women to end the violations of their private life (Van der Aa 2010, p. 237).

${ }^{4}$ OJ 18.03.2010, C69/5.

5 At least, this is what the Explanatory Memorandum of the Directive on the European Protection Order suggests (5677/10 COPEN 28 of 22 January 2010). Whether this assumption is true and whether all European Member States have such protection measures available will be discussed in this article.

${ }^{6}$ This assumption can be deduced from the requirement that, according to the initiators, the executing state has to provide the victim with a level of protection that is 'similar to that provide by the State whose authority adopted the initial measure and equivalent to that provided to other victims in the executing State' (Explanatory Memorandum, p. 12) [italics added].

${ }^{7}$ Now, the executing State has to adopt a measure that would be available under its national law in a similar case and which corresponds, to the highest degree possible, to the protection measure ordered in the issuing state (Art. $9(1)(2))$.
} 
question: What sort of protection order legislation do the 27 Member States have and what exactly is the current level of protection that Member States are able to provide to victims?

A good overview of the current state of affairs in protection order legislation in the European Member States is first of all important from an inspirational point of view: A decent analysis of protection order legislation can benefit not only the Member States that are contemplating the enactment of such legislation, but also the Member States that have already installed certain provisions. The latter states will be given the opportunity to place their national laws against the (European) yardstick: Does their national law live up to the standard or should certain changes be made? Another reason is that although the EPO is based on mutual recognition, not harmonization, in practice mutual recognition becomes very problematic when there is not a certain level of uniformity amongst protection measures. ${ }^{8}$ Accordingly, for a proper functioning of the EPO, an overview - possibly followed by an approximation - of legislation is important.

In order to assess the current state of affairs in protection order legislation in the $27 \mathrm{EU}$ Member States, the term 'protection order' first needs to be defined ("The Definition of a Protection Order"). The delineation of the term will be followed by a brief discussion on the effectiveness of protection orders ("The Effectiveness of Protection Orders"). After all, what use is there in enacting protection order legislation if empirical research has not found any positive effects on the reduction of the repetitive behavior or on the well-being of the victim? In "Research on Protection Order Legislation in the EU Member States", a description will be given of the five research projects that have touched upon the issue of protection order legislation in the EU Member States, followed by a description of the results of these studies in "Taking Stock of Protection Orders in the EU Member States" on a state-by-state and on a more abstract level. By combining the results of these five studies we are able to catalogue protection order legislation in the Member States more accurately, compared to relying on any one of these studies alone. The synthesis of the five studies will be summarized in a table (Appendix). A possible strategy to enable the approximation of protection order measures in the EU Member States will be presented in "Possible strategies to enable the approximation of levels of protection in Europe" and the article will finish with an overall conclusion (“Conclusion”).

\section{The Definition of a Protection Order}

The question of how a protection order should be defined is not a straightforward one. The problem is that there is no universally accepted definition. The majority of definitions is based on national legislation which only apply to the domestic situation. Given that protection order legislation varies per country, these definitions cannot easily be transposed to other jurisdictions. If we, for instance, focus on criminal protection orders, we find that there are many means, pre-trial as well as post-trial, in which the criminal justice system can impose restraints upon a suspect or a convicted offender in order to protect the victim. In some countries the courts have the possibility to suspend the sentence under the condition that the offender desists from contacting the victim. Another option is to have the courts

\footnotetext{
${ }^{8}$ The instrument of mutual recognition was first intended as an alternative to harmonization of national criminal procedural law, but this position has changed over the years. The Hague Programme expresses that 'the development of equivalent standards for procedural rights in criminal proceedings' would be necessary for a workable mutual recognition system (Hague Programme, OJ 2005 C 53, Ch 3, Sect. 3.3.1.). In other words, a minimum level of harmonization or approximation of laws seems essential.
} 
impose a protection order as an autonomous sanction, independent of another (suspended) sentence. In yet other countries, the police can issue a formal warning, the public prosecutor can impose a protection order in exchange for a waiver from prosecution, or the courts can attach a protection order to probation or to an early release from prison. In the UK and Ireland, the courts can even impose protection orders after the acquittal of the accused. A description of a criminal protection order as: 'a release from [preventive] custody under certain conditions' (Malsch and Smeenk 2005, p. 227) would therefore be too narrow to capture the wide spectrum of protective measures.

To complicate matters even further, various synonyms of the concept 'protection order' are in circulation. In Anglo-Saxon jurisdictions you can find equivalent or closely related terms such as 'protective order', 'restraining order', 'stay-away order', 'no-contact order' or 'injunction order' and the non-English speaking countries generally use national terminology. On top of that, protection orders can not only be imposed as part of the criminal justice procedure, but can also play a role in civil and administrative proceedings.

According to the European Parliament's position on the EPO, a protection measure means:

A decision adopted in the issuing State in accordance with its national law and procedures by which one or more of the obligations or prohibitions as referred to in Article 5 are imposed on a person causing danger to the benefit of a protected person with a view to protecting the latter against a criminal act which may endanger his life, physical or psychological integrity, dignity, personal liberty or sexual integrity. (Art. 2(2))

The obligations or prohibitions as referred to in Article 5 are: a) a prohibition from entering certain localities, places or defines areas where the protected person resides or that he visits; b) a prohibition or regulation of contact, in any form, with the protected person, including by phone, electronic or ordinary mail, fax or any other means; or c) a prohibition or regulation on approaching the protected person closer than a prescribed distance.

Although the definition chosen by the European Parliament certainly has strong points, for the current article it is not inclusive enough. First of all, there are more types of obligations and prohibitions which can be included in a protection order, not just the ones enumerated in Article 5. ${ }^{9}$ Also, in light of the fact that stalking has not (yet) been criminalized in all the 27 Member States, the restriction to 'protecting the latter against a criminal act [italics added]' may be too restrictive as well. In this article, the idea is to cast the net as widely as possible so that all possibly relevant orders that aim to enhance the protection of victims are included when we take stock of the current state of affairs in "Taking Stock of Protection Orders in the EU Member States". We will therefore take on a broader definition of the term protection order, namely:

Any decision, provisional or final, adopted by a civil, criminal or administrative court or other judicial authority, imposing rules of conduct (obligations or prohibitions) on a person causing danger with the aim of protecting another person against an act which may endanger his life, physical or psychological integrity, dignity, personal liberty or sexual integrity.

As long as a court or another judicial authority has imposed certain restrictions or prohibitions on a person with the aim of protecting another person it is irrelevant what type

\footnotetext{
${ }^{9}$ In the Netherlands, for example, civil courts have imposed prohibitions on contacting the victim's family and friends, prohibitions to study at a certain educational institute, or even the positive obligation to relocate to another area (see Hes and Van Ringen 1986, p. 96).
} 
of court did this or how the exact protective provision is legally qualified. However, (protection) measures involving physical incapacitation of the offender (e.g., preventive custody) or 'target hardening' (e.g., victim anonymity, police protection of the victim) will not be taken into account in this article. Only legal instruments imposing rules of conduct aimed at influencing the behavior of the offender are of interest here (see also Brienen and Hoegen 2000, p. 1151).

\section{The Effectiveness of Protection Orders}

Protection orders have an intuitive appeal: If effective they procure exactly what the victim wants, namely to be left alone, yet it is exactly their effectiveness that is contested (Malsch 2004, p. 30). After all, a protection order is often nothing more than a legal document issued by a judicial authority telling the restrainee to stay away from the person protected by the order. Of course, protection orders are generally strengthened by some sort of penalty upon violation, but given the determination of certain stalkers or batterers and given the sometimes inadequate follow-up by law enforcement officers, it is legitimate to ask the question of whether protection orders are actually effective in practice. In other, more popular, words: Can a piece of paper stop a bullet?

In the past, some studies have been conducted into the effectiveness of civil and criminal protection orders. ${ }^{10}$ Due to disparate definitions of effectiveness, varying research methods, and differences in the legal systems under scrutiny, the outcomes of these studies vary significantly. One of the landmark studies in stalking research showed that $69 \%$ of the female and $81 \%$ of the male victims reported a violation of the protection order by their stalker (Tjaden and Thoennes 1998). Furthermore, only 1\% of the victims attributed the end of the stalking to a protection order.

Other studies, however, have generated more encouraging results. According to the court and police files of a random sample of 240 Finnish stalking cases in which a protection order had been issued, $35 \%$ of the stalkers violated the order (Häkkänen et al. 2003). Amongst the stalkers who had violated the order, there was a significant decline of the proportion of restrainees employing violent stalking actions and threats. Although the issuing of a protection order did not affect actions like making telephone calls, sending text messages, sending letters, making visits and keeping surveillance, the proportion of those who physically assaulted the victim decreased from $80 \%$ to $17 \%$ following the issuance of the order. Similar positive results were found in the prospective study of Logan et al. (2009). Of the 227 women who had obtained a civil protection order against a male intimate partner half $(50 \%)$ reported a violation of the order during the first six months. Among those who experienced violations, the violence was significantly less severe than before.

If effectiveness is furthermore understood to include victim satisfaction, and victims' feelings of safety and happiness, protection orders definitely seem to have a positive effect. Of the 285 female domestic violence and stalking victims who had petitioned for a protection order in Keilitz et al.'s (1998) study, 72\% reported no continuing problems one month after the issuance of a temporary or permanent protection order, which decreased to $65 \%$ after six months. But despite the occasional incidence of stalking and assault after the

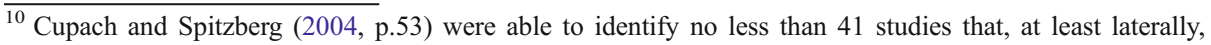
assessed the effectiveness of protection orders.
} 
protection order was imposed, many women reported an improvement in their quality of life. ${ }^{11}$

A quasi-experimental study by Vogt and Greeff (2010) into the effectiveness of interim protection orders in South-Africa compared victims of domestic violence who had been granted an interim protection order $(n=884)$ to victims of domestic violence who had not been granted such an order $(n=125)$. Although the results indicated that the interim protection orders did not significantly contribute to a reduction in total abuse exposure (both groups experienced a similar reduction from the first to the second measurement), the orders did contribute significantly to a reduction in total impairment, health status issues, concern with physical harm, psychological dysfunction, life restriction, inadequate life control and relationship disability.

Despite the fact that the studies generate different results, the overall tendency is to attribute at least some positive effects to protection orders; if not (mainly) in the overall reduction of abuse or stalking exposure, then at least in the improvement of the victims' sense of well-being. All in all, protection orders generally seem to have a positive impact on victims of stalking and domestic violence and it is therefore worthwhile to further investigate the way they have been incorporated by the different Member States.

\section{Research on Protection Order Legislation in the EU Member States}

The European Member States harbor a plethora of protection order schemes. Apart from the finding that there are 27 different protection order schemes out there - a finding which in itself complicates matters greatly - there is also another complicating factor: The different protection schemes in the European Member States have never been the subject of careful study. As of late, certain research projects have touched upon the issue, but only sideways and, as a result, the research projects have only managed to scratch the surface of the various victim protection laws in the European Union. Recent research projects in which criminal or civil protection orders appeared were: the dissertation by Brienen and Hoegen (2000), the study by the Modena Group on Stalking (2007), the study by Van der Aa et al. (2009), and the European Commission's Feasibility study (2010). Furthermore, in 2009, within the context of the preparatory works for the European Protection Order, the Member States were asked to fill out a questionnaire on their native protection order regimes (hereafter: EPO questionnaire). ${ }^{12}$

These five sources will form the basis of the narrative in "Taking Stock of Protection Orders in the EU Member States". However, before the outcomes of the various studies are described, a caveat needs to be made. The research projects generally relied on (legal) experts to explain the intricacies of their national victim protection regimes. Given that not all these experts were equally fluent when it came to their working knowledge of English, the quality of the responses varied sometimes. There were also variations in the sense that certain experts had been more elaborate than others and that some experts seemed to be somewhat less familiar with the topic at hand. A specific limitation of the multiple choice

\footnotetext{
${ }^{11}$ In the initial interviews, $72 \%$ of the participants reported that their lives had improved. This increased to $85 \%$ during follow-up interviews. Furthermore, $90 \%$ felt better about themselves and $80 \%$ felt safer. Respondents in Logan et al.'s study (2009) also reported reduced fear of future harm in comparison to the baseline measurement.

${ }^{12}$ Note from the General Secretariat to the Working Party on Cooperation in Criminal Matters on the European Protection Order (Answers by delegations in reply to the questionnaire), Council Document No 5002/10 COPEN 1 of 6 January 2010.
} 
questionnaire that was used by some studies (e.g., Van der Aa et al.; the European Commission's feasibility study) was that occasionally the questions may have been interpreted differently. Furthermore, the Modena Group on Stalking's research only focused on stalking, not domestic violence. Finally, certain studies had not incorporated all the current EU Member states, either because at the time of writing these countries had not yet acceded to the European Union (e.g., Brienen and Hoegen 2000), or because countries had neglected to respond to a request for information. ${ }^{13}$

Due to the different research methods and designs, the outcomes of the five research projects sometimes differed and, on occasion, even contradicted on another (see Appendix). Some irregularities in the data could be corrected with the help of 'triangulation': by comparing the information of the five sources, the correct interpretation would surface. But sometimes the information only appeared in three or less sources, or the information in a certain source was too dodgy or incomplete to derive any reliable conclusions thereof. What follows is, by necessity, only a marginal and, on occasion, perhaps even inaccurate representation of the legal reality in the Member states. Where possible, any apprehension on the part of the author as to the correctness of the information was indicated, but the reader is advised to interpret the results with care nevertheless.

\section{Taking Stock of Protection Orders in the EU Member States}

\section{Protection Orders per Member State}

Austria The general picture is that in Austria, victim protection is mainly regulated by means of civil interim injunctions with a maximum of 12 months and a possibility of extension upon violation. The violation of the injunction is a civil law offence. Although the criminal procedure also provides certain possibilities for protection (conditions to a suspended sentence or - possibly - a preventive custody) this is not core business. Apart from the barring order which can be imposed by the police, (long-term) protection mainly has to be procured through civil courts.

Belgium All five sources agree that in Belgium, both civil as criminal protection orders are readily available. Within criminal procedural law a conditional release from preventive custody and a conditionally suspended sentence are possible. Within civil procedures, the victim can ask for a protection order as well, although a violation of the order is not criminalized, but carries a civil penalty. Belgium has not introduced the barring order yet, but a legislative proposal to that end has been initiated and is currently being discussed in the Senate.

Bulgaria The Bulgarian criminal law system allows the criminal court to impose a penalty which restrains the free movement of the offender (Art. 42a CC). The following three prohibition measures are allowed: 1) a prohibition to attend certain areas, locations or establishments, 2) a prohibition to leave a populated area for more than 24 hours without permission of the public prosecutor or probation officer, and 3) a prohibition to leave his/her residence during certain hours of the day or night. These prohibitions, however, are only intended as a means to punish the offender, not as a protection mechanism for the victim (EPO questionnaire, p. 6). There are no reports of pre-trial criminal protection measures and barring orders seem to be

\footnotetext{
${ }^{13}$ Seven Member states had, for example, not responded to the questionnaire on the European Protection Order (Cyprus, Greece, Hungary, Ireland, Luxemburg, Malta and Romania).
} 
absent as well. As for civil protection orders, these are only available to victims of domestic violence. The violation of civil protection orders is criminalized.

Cyprus Criminal protection orders in Cyprus are only available to victims of domestic violence and trafficking. Probably, these are all post-trial orders (suspension of the sentence, autonomous protection order). If a person exhibits 'threatening behavior' a victim can file for a civil protection order against the offender, violation of which is criminalized. Barring orders are not available.

Czech Republic The Czech criminal law protection orders are limited to the post-trial stage (conditional suspended sentence, conditional release, and autonomous protection order) and, possibly, only a particular type of victim (former spouses, former cohabitants) is eligible. An interim civil measure can be imposed if the plaintiff's life, health, freedom or human dignity is in danger and a violation of the measure is a criminal offence. The Czech legislator has recently introduced the barring order.

Denmark The most important and perhaps only source of victim protection in Denmark seems to be the orders administered by the police on the basis of Article $265 \mathrm{CC}$. If a person 'violates the peace' of another person, the police can issue a caution, usually on the request of the victim. It is not required that the violation of the peace constitutes a criminal offence. The caution remains valid for 5 years and a violation of the caution is criminalized. Only one source mentions the presence of civil protection orders, but none of the others. In cases of domestic violence, there are barring orders available.

Estonia Post-trial, if the offender is convicted of a crime, the victim can request the court to impose an autonomous criminal protection order with a term of up to three years (Art. 310 $\mathrm{CCP}$ ). Pre-trial, the public prosecutor, the preliminary judge or the court can decide on criminal protection measures. Civil protection orders are available as well and violations are criminalized. There are no barring orders available.

Finland In Finland, the Act on Restraining Orders provides for the majority of protection orders. The result is neither a purely criminal, nor a purely civil order. The order can be obtained in a quasi-criminal procedure that is not necessarily - not even usually - connected to a criminal prosecution. The victim, the police, the public prosecutor and social service workers can all apply for an order under the Act and the police are obliged to carry out an investigation as to the desirability of the order. In emergency situations, the police can issue an interim protection order. The violation of such a protection order is a criminal offence. Next to the orders under the Act on the Restraining Order, the courts can also impose orders in the course of a criminal procedure, but most orders are granted under the Act. On top of that, victims can also be protected by means of a barring order.

France During the pre-trial stage the examining magistrate can order the suspect not to leave a certain area or to attend a certain place, while in the post-trial stage the courts can order the offender to refrain from contacting the victim as a condition to a suspended sentence. In France, the criminal procedure is the most important gateway to a protection order. Civil protection orders - if present at all - probably only extend to the eviction from a violent spouse from the home in case of divorce proceedings. There are no barring orders. 
Germany In Germany, autonomous criminal protection orders do not exist, but the court can give instructions to the offender in the context of a suspended sentence or a supervision of conduct. There was little information on pre-trial protection, possibly because it is absent. Civil protection orders, on the other hand, are widely documented. Under the Protection from Violence Law (and possibly other, more general civil procedures) the victims of domestic violence and stalking can file for civil protection orders. Infringements are criminalized. Germany has furthermore recently introduced the barring order.

Greece When it comes to protection orders, the situation has recently improved in Greece. Before the introduction of the Domestic Violence Law of 2006 protection orders could be imposed, both pre-trial as post-trial, but mainly with the security of the suspect in mind. Threatened victims often had no alternative than to ask for police protection. Now, if victims meet certain criteria, they can request for a protection order which can be imposed by the criminal court, investigative judge or the judicial council. The Law also created the possibility to apply for interim protection orders in civil court. Although the data are somewhat contradictory, it seems as if a violation of a civil protection order can constitute a criminal offence. ${ }^{14}$ Greece has not introduced the instrument of the barring order.

Hungary In Hungary, the rules for protection orders are laid down in the Act on Restraining. This Act only applies to relatives, (ex)spouses, and (ex)partners. The Act provides for two forms of protection orders: 1) a police-ordered temporary protection order of three days, and 2) a court-ordered civil protection order which lasts longer. The latter can be requested by the police or the victim. In the context of criminal proceedings, it is also possible to impose protection orders as a 'coercive measure'. The 3-day police order is considered a barring order in Hungary.

Ireland In a criminal procedure, protection orders can be imposed by the courts in addition to or as an alternative to other sanctions. Even upon acquittal, the criminal protection order can be imposed. There is no information available on pre-trial protection orders. Victims can furthermore apply for civil protection orders under general civil tort law (violation of which is criminalized) and Ireland has also introduced the barring order.

Italy As of 2009, the victim can ask the police to caution the offender (e.g., to stop the harassment). If the offender does not adhere to this caution, the crime of stalking can be prosecuted even without the otherwise required private complaint and it is an aggravated offence. One source furthermore mentions the option of protection measures in the enforcement phase of a conviction (EPO questionnaire), but two other sources complain about the limited means of the judicial authorities to protect the victim in both the pre- as the post-trial phase (Modena Group on Stalking (2007) and Brienen \& Hoegen (2000)). Protection orders are furthermore available in civil proceedings on the basis of the 2001 civil law on protection orders, but possibly only when domestic violence is concerned or when the stalking occurs in the context of cohabiting partners. The goal is to enforce a separation from the violent partner. Violation of the civil orders is a criminal offence. Italy does not have barring orders.

\footnotetext{
${ }^{14}$ In the Modena Group on Stalking (2007) report, it says that the violation of a civil protection order is a civil offence, whereas the European Commission's feasibility study (2010) claims that violations are criminalized (Art. 232a CC). Perhaps both options are possible or perhaps the law has changed over the years.
} 
Latvia In Latvia, it seems as if the criminal procedure only provides for pre-trial protection. As of 1 October 2005, the victim can request for a protection order which can be imposed by the police or the public prosecutor and which is valid until the final court decision. The European Commission's feasibility study reports that this measure, which was supposed to benefit victims of domestic violence, is rarely applied. There does not seem to be a possibility to apply for civil protection orders and the instrument of the barring order is absent as well.

Lithuania Criminal protection orders can be imposed by an investigative judge, by the public prosecutor or by a court (pre-trial) and there is also an autonomous penalty which can restrain the offender to approach the victim (post-trial). In cases of domestic violence, the court can furthermore decide to separate the offender from the victim (Art. 132(1) CCP). Civil protection is less well organized: only in the context of a divorce (caused by domestic violence) can civil protection orders be imposed, and they are only valid until final judgment. Infringement of the temporary order results in criminal liability for not complying with a court decision. There are no barring orders available.

Luxemburg Whether or not criminal protection orders are present in Luxemburg remains somewhat obscure. Whereas the Modena Group on Stalking (2007) claims that protection orders specific for stalking have been introduced in both civil as criminal law, the European Commission's feasibility study (2010) refutes this. According to the European Commission's report there are no criminal protection orders for victims of crime, but Brienen \& Hoegen at least mentions the possibility of a conditional suspension of the sentence or a conditional release from prison. The same ambiguity surrounds civil protection orders: the Modena Group on Stalking (2007), Brienen \& Hoegen (2000) and Van der Aa et al. (2009) mention the presence of civil protection orders, but according to the European Commission's feasibility study, there is only the option to file for long-term protection after the domestic violence offender has been expelled from the home as a result from the barring order (which has been introduced in Luxemburg). A violation of the order is criminalized.

Malta While victims previous to the enactment of the Domestic Violence Act were forced to rely on police protection before and after the trial, the courts can now issue a criminal protection order in cases of domestic violence and harassment. Even pre-trial protection orders are mentioned, but only by one source (Modena Group on Stalking 2007) and they do this so ambiguously, that the presence of pre-trial orders should be questioned. Civil protection orders are available, but seem to be restricted to cases of divorce. Malta does not provide for the possibility of barring orders.

The Netherlands In the Netherlands, both pre-trial (conditional release from preventive custody, conditional waiver of the prosecution) as post-trial (conditional suspension of the sentence, conditional release from prison) protection are taken care of. There is now even a bill pending which proposes the introduction of protection orders as an autonomous measure, in addition to or as an alternative to other sanctions. A victim can furthermore apply to the civil court for a protection order, but the infringement of such an order is not a crime. On 1 January 2009, the barring order was introduced.

Poland In Poland, there are both pre-trial and post-trial measures (custodial and suspended sentence) available. As of 8 June 2010 the preventive custody can be suspended on the condition that the offender submits him-or herself to 'police surveillance'. There are two 
problems with this construction: 1) stalking is not criminalized in Poland, so the preventive custody could not have been imposed in the first place, and 2) the requirements for a preventive custody are so strict, that even cases of domestic violence would not be able to meet the criteria. The status of civil protection orders is unclear: two sources claim that there are no civil protection orders available (Van der Aa et al. 2009; EPO questionnaire), one source reckons that the introduction of civil protection orders is currently under consideration (European Commission's Feasibility Study 2010), and one source states that the civil law does have an article which aims to protect 'personal interests' and which can form the basis for protection orders (Modena Group on Stalking 2007, violation is not criminalized). There are no barring orders available.

Portugal In Portugal there is a wide variety of criminal protection orders in all stages of the procedure. During the pre-trial stage the examining magistrate can order the suspect to refrain from contacting the victim or from visiting certain areas, but anecdotal evidence suggests that magistrates are not inclined to use this option in practice (Brienen and Hoegen 2000, pp. 789-790). Post-trial, criminal protection orders can be imposed as part of a suspended sentence, a probation or a conditional release from prison. Civil protection orders appear to be absent, just like barring orders.

Romania Given that Romania was only included in one study (European Commission's Feasibility Study 2010), the results could not be verified by the other four sources. This could have serious implications for the reliability of the result. At the time of the European Commission's study, a bill was proposed which aimed to introduce the possibility of requesting criminal protection orders, an option which was currently unavailable in Romania. Also, there were no relevant civil protection orders for stalking or domestic violence victims, nor were there barring orders.

Slovakia In Slovakia, all criminal justice agents have options to restrain the offender. The police can impose protection orders, albeit that these are limited in time, and they can evict the offender of domestic violence from the family home for the duration of 48 hours. The public prosecutor can bargain certain conditions in exchange for a waiver of the prosecution and the courts can impose a protection order, albeit not as an autonomous penalty. Civil courts can also issue a temporary injunction, the violation of which is a crime. The 2-days removal of the domestic offender from the family home constitutes a barring order according to the Slovakian experts.

Slovenia The sources are somewhat unclear, but it seems as if in Slovenia, criminal protection orders are only available before and during the trial (e.g., as a substitute for pre-trial detention). Furthermore, the police may restrain a person if the suspect committed an offence and 'there are reasons to suspect that he or she will threaten the life, personal safety or freedom of the person with whom he or she was or is in a close relationship'. ${ }^{15}$ If civil protection orders are available, they only apply to cases of domestic violence and they either have a very long processing time (under the Family Violence Act), or they only serve to remove the offender from the family home in cases of 'ongoing matrimonial disputes between spouses' (Civil Procedure Act). A violation of the order does not carry a penalty. Barring orders can be imposed.

${ }_{15}$ The EPO questionnaire mentions as an additional requirement that the suspect has to have been caught in the act by the police while committing the crime. 
Spain In Spain there is a wide variety of criminal protection orders available, both pre-trial as post-trial. Especially in cases of domestic and/or gender violence, the (domestic violence) courts have an impressive armamentarium at their disposal. Civil protection, however, seems to be practically absent, and this is also true for the barring order.

Sweden In Sweden, under the Restraining Order Act of 1988, the legislator created a separate, administrative procedure which allows victims to apply for a protection order. The decision lies in the hands of the public prosecutor and a protection order can also be granted if there is insufficient evidence that an actual crime has taken place. A violation of the order is criminalized. Apart from this administrative procedure, there are no other venues for victims to obtain a protection order.

United Kingdom (Sometimes Only England and Wales) Crime victims in the UK can receive protection at all stages of the criminal procedure. Under the Protection from Harassment Act of 1997, a protection order can even be granted after an acquittal of the suspect. The only criterion is whether 'the court considers it necessary'. Civil protection orders can also be applied for (e.g., non-molestation orders). Whether violations are criminal depends on the type of order granted by the civil court. Barring orders are absent, but they will be introduced shortly.

\section{Overall Assessment of Criminal Protection Orders}

Using the broad definition from "The Definition of a Protection Order", we can conclude that practically each Member state has some form of criminal protection order in place with one (possible) exception: Romania. ${ }^{16}$ It seems that the criminal justice system in this country does not provide any form of victim protection, not yet at least.

As for the countries that do have criminal protection orders in place, these orders come in many shapes and sizes and the level of protection provided by them varies accordingly. In Italy, for instance, criminal protection orders can only be imposed by the police: the police can caution the offender not to contact or come near to the victim anymore. However, the lack of other criminal provisions to protect the victims is heavily criticized. Another difference that can seriously limit the level of protection is the absence of protection during some parts of the criminal procedure. In some Member states, the criminal justice system does not provide protection before there is a final judgment (e.g., Luxemburg, Bulgaria, Czech Republic). In these countries the criminal courts can only impose protection orders after the case has resulted in the conviction of the accused. In other countries, the exact opposite is true: there only pre-trial protection orders can be issued which are valid until the final judgment (e.g., Latvia and Italy). Of course, having both pre-trial as post-trial orders available (e.g., the Netherlands, Belgium) or perhaps an alternative, administrative order which can account for a vast period of time (e.g., Finland) is to be preferred. Another factor that can seriously hamper adequate victim protection is the restriction of criminal protection orders to a limited range of victims only. In Cyprus and possibly also Greece, for example, the orders are available to victims of domestic violence and/ or human trafficking, but not to others. As a result, victims who are stalked by people other than their (former) partners cannot benefit from the orders.

For victims of stalking, there is one final obstacle that is probably even more problematic than all the aforementioned barriers to obtaining a criminal restraining order and that is the fact that

\footnotetext{
${ }^{16}$ In Appendix Table 1, Sweden is also excepted, but at least Sweden has an alternative administrative procedure, which can be initiated by the victim and which can be pursued independent of a criminal procedure. This way, victims can seek protection for a period of time which can cover the period before and after a criminal trial.
} 
criminal restraining orders can only be imposed when suspicions of a crime have arisen. Since 15 Member states have not criminalized stalking, victims who are stalked in those jurisdictions are practically left empty-handed. Unless the stalking consists of behavior that is criminalized elsewhere in the Criminal Code, criminal restraining orders will not be available to them.

\section{Overall Assessment of Civil Protection Orders}

Civil protection orders are orders issued by civil courts restricting a person from a certain activity with an eye on the protection of the plaintiff. Civil protection orders can be temporary or permanent, but they are usually restricted in time, although often the orders can be extended, for example, because the restrainee violated the orders. The orders can encompass a variety of prohibitions, but they generally hold the prohibition to visit the protected party's home and/or workplace, to enter a certain area, and/or to initiate contact with the protected party. Most of the time, civil protection orders are sought to provide parties with immediate relief. The civil (interlocutory) procedures often take up little time and the evidence does not have to live up to criminal law standards. Another advantage of civil protection orders is that the victim can act independently of the cooperation of the police, a feature which could be very important in cases of stalking (see "Overall Assessment of Criminal Protection Orders").

Given these advantages of civil protection orders over criminal protection orders, it is remarkable, that five, but possibly more, Member states do not permit their citizens to apply for a civil protection order. ${ }^{17}$ In comparison, American stalking victims are much better off: all states allow individuals to seek a civil protection order when they are subjected to harassment or stalking by another person. In Europe the absence of civil protection orders in some Member States probably has to do with long-standing legal traditions. Perhaps it is considered a violation of the principle of subsidiarity to limit the freedom of movement of an individual based on nothing more than a civil (interim) lawsuit, with the often lenient rules of evidence that govern these procedures.

Another feature that puts certain victims at a disadvantage is the fact that even in Member states where civil protection orders are available, not all victims have access to them. The Slovakian and Slovenian experts, for example, indicated that they are not sure whether a complaint of stalking would suffice to convince the civil courts of the necessity of a protection order (European Commission's feasibility study 2010). Furthermore, in Romania, not a single case of stalking has come before a civil court yet. Also in some Member states (for certain in Bulgaria, Hungary, Slovenia and Lithuania, but possibly also in Malta, Italy and Luxemburg) the protection only extends to (former) victims of domestic violence or to (ex) spouses and relatives. ${ }^{18}$ As a result, victims who are stalked by acquaintances, by strangers, or sometimes even by ex-partners with whom they were not married or did not enter into a registered partnership with are deprived of this type of protection. And even when the interim measure is de jure unconnected to the prior relationship of the stalker and his/her victim, it happens that de facto the orders are practically only imposed in domestic violence situations, for example, as a follow-up to the eviction of the offender from the conjugal home. ${ }^{19}$

\footnotetext{
${ }^{17}$ Although Finland does not offer civil protection orders, it does have a special procedure to obtain protection measures that is neither criminal, nor civil. What matters is that victims can apply for a protection order through those proceedings independent of a criminal proceeding. The same line of reasoning goes for Sweden. ${ }^{18}$ The protection order in Lithuania has even more restrictions, given that only spouses can apply in the course of divorce proceedings and the order is only valid until the final judgment.

${ }^{19}$ This remark was made by the Czech expert in her national report (European Commission's Feasibility Study 2010).
} 
A final area in which a difference between the civil mechanisms of protecting the victim arises is the manner in which civil protection measures are enforced. Thirteen Member states have criminalized a violation of a civil restraining order, often because it constitutes a 'contempt of court' or because it 'frustrates the execution of a court decision'. Austria, Belgium, the Netherlands, and Slovenia have not criminalized violations. ${ }^{20}$ If a protection order is breached in those countries, the civil courts can levy a fine, or sometimes they can even confine the offender, but this is based on civil law instead of criminal law. Which enforcement mechanism should be preferred is unclear. There is no empirical evidence that supports the one solution over the other and there are things to be said for either. An advantage of criminalization over civil law enforcement, is that sometimes the police can intervene quicker and with more severity than, for example, a bailiff who is charged with the enforcement of breaches of a civil restraining order. On the other hand, the knowledge that a violation could send the violator to prison could be an impediment to victims who do not wish to stigmatize their offenders (e.g., because he is also the father of her children). As a result, they might not want to inform the courts of any violations that may have taken place. Anecdotal evidence, however, suggests that - regardless of whether a violation is criminalized or not - enforcement does not come up to the mark anywhere.

\section{Overall Assessment of the Barring Order}

The emergency removal or barring order allows the police or the public prosecution service to remove the offender of domestic violence from the family home for a limited period of time (usually 10 days). ${ }^{21}$ It appears that this measure is quickly gaining popularity within the European Union. Eleven Member States have recently implemented measures that could more or less qualify as a barring order, while some other Member States are in the middle of a legislative procedure to that end. ${ }^{22}$ The first, mostly explorative, studies into the usefulness and effectiveness of the barring order are positive. ${ }^{23}$

Although legislation on the barring order is fully in motion, already striking differences between the Member States which have implemented the measure are becoming visible. To begin with, there are large differences in the duration of the ban. In Slovakia, the police can only order the offender to stay away for a maximum period of 48 hours, whereas in other countries the order typically lasts for 10 days (with a possibility of prolongation). The question is whether a shorter time span provides enough time for the parties to calm down or to enable the victim to apply for longer-lasting protection. Although not extensively dealt with in the previous sections, there also seem to be deviations in the extent to which assistance is offered to both offender and victim. In some Member States the removal from the family home and aid to both offender and victim come as a package deal. Whenever a barring order is imposed, assistance agencies are automatically alerted and assigned to the family. Other Member States, on the other hand, have opted for a less sophisticated approach with a primary focus on short-term safety by removal of the perpetrator, not long-term solutions.

\footnotetext{
${ }^{20}$ The consequences of the violation of a civil protection order in Hungary and Romania are unclear.

${ }^{21}$ Needless to say that the typical stalking victim will not be able to profit from the barring order, since the barring order is only imposed when victim and offender share certain premises. Usually, the stalker does not live together with his or her victim and if so, the harassment would rather fall within the realm of domestic violence instead of stalking.

${ }^{22}$ In Belgium, for example, a bill to this extent was initiated by senator Sabine de Bethune. In England legislation on the barring order is expected any time now.

${ }^{23}$ For examples of those studies, see the Dutch website www.huisverbod.nl.
} 


\section{Possible Strategies to Enable the Approximation of Levels of Protection in Europe}

The foregoing was not an exact assessment of the level of protection provided to victims in the EU Member States. Comparing legal regulations is too blunt an instrument to base specific conclusions relating to the level of protection on. An adequate comparison of the different protection levels would also require the development of objective, standardized criteria against which the different protection orders could be measured ${ }^{24}$ and an assessment of the workings of protection order legislation in practice. What the overview has shown instead is that in some Member States there seem to be considerable gaps in victim protection legislation, for example, because there is no pre-trial protection in criminal proceedings or because civil protection orders are not available. This will inevitably have a bearing on the level of protection. Although the data are sometimes questionable and even contradictory, the general picture that emerges - of a huge variation in levels of victim protection across the EU - seems correct.

Given the emphasis on victim protection in various international legal documents and rulings, ${ }^{25}$ this situation no longer seems tenable, certainly not in the long run. Another factor, which even adds a sense of urgency to the matter, is the forthcoming introduction of the European Protection Order. The instrument of mutual recognition is by necessity often accompanied by a form of minimum harmonization. It will, for example, be very complicated for a Member State to recognize a criminal pre-trial protection order and to substitute it by a native equivalent if there are no criminal pre-trial protection orders available in the national legal order (see Van der Aa and Ouwerkerk 2011).

However, in the current political climate - heavily influenced by the financial crisis chances are small that Member States would be in the forefront when it comes to adopting new, possibly costly procedures to meet the needs of victims. An incentive in the form of EU regulation could enhance the situation, but the problem is that the EU is only competent to adopt binding (harmonizing) legislation in case of cross-border issues and this is not selfevident in the case of national protection order regimes.

\section{Approximation Through Co-regulation}

Given that there is a limited legal basis for harmonization of the national legislation on the basis of binding legislation, we will have to explore the possibilities of non-binding alternatives. A first option could be to place more emphasis on compliance with Article 8 of the Framework Decision on the standing of victims in criminal proceedings, which states that '[e]ach Member State shall ensure a suitable level of protection for victims and, where appropriate, their families or persons in a similar position, particularly as regards their safety and protection of their privacy, where the competent authorities consider that there is a serious risk of reprisals or firm evidence of serious intent to intrude upon their privacy'. As two evaluation reports have shown, many of the Member States are not fully in compliance

\footnotetext{
${ }^{24}$ What is, for instance, the level of protection provided by civil protection orders in comparison to the level of protection provided by criminal orders?

${ }^{25}$ Providing adequate protection to (domestic violence and stalking) victims is now more and more seen as a human right (e.g., European Commission's feasibility study 2010; Meyersfeld 2010). See also the ECtHR ruling of 2009 in the case of Opuz v. Turkey in which the Court ruled that the failure of the state to provide adequate protection to women who are obviously at risk of being violently abused by an intimate (ex)partner, constitutes a violation of the right to life (Article 2 ECHR) and a violation of gender equality (Article 14 ECHR). States have a positive obligation to take preventive operational measures to protect an individual from criminal acts of another person where they 'knew or ought to have known' of a 'real and immediate risk to the life of (an) identified individual(s) from the criminal acts of a third party and they failed to take measures within the scope of their powers which, judged reasonably, might have been expected to avoid that risk.'
} 
with this particular provision of the Framework Decision (nor any of the other provisions for that matter). ${ }^{26}$ Although, as a result of the disappointing evaluation, the European Council did call on the Commission and the Member States, among other things, to 'examine how to improve legislation and practical support measures for protection of victims and to improve implementation of existing instruments', it may want to consider trying to get Member States even more involved, for example, by means of co-regulation.

Co-regulation relates to an EU legislative act, in which parties are recognized in the field (e.g., NGO's, social partners), which are entrusted with the attainment of the objectives in the legislative act. In other words, these other parties help with the implementation of the act and, as such, co-regulation is a complement to legislation rather than an alternative. Whereas the legislator defines and codifies the general norms and the fundamental principles, the 'interpretive community' plays a role in the interpretation and the elaboration of these norms and principles. By involving non-governmental actors and by using a less intrusive legal instrument, States may be more willing to accept the contents of the legal act and it may generate more legitimacy and commitment. ${ }^{27}$

Translated to our example of Article 8, the European legislator may want to create legislation in which an interpretive community is appointed, which could in turn specify what, for example, 'a suitable level of protection', would entail exactly. Article 8 does not literally prescribe the implementation of criminal protection orders, but possibly the interpretive community could come to the conclusion that this would be an absolute minimum to guarantee the required 'suitable level of protection'. The European legislator could also codify this general minimum standard himself, and then leave it up to the interpretive community how to implement the norm in practice. $^{28}$

\section{Approximation Through the Open Method of Coordination}

A problem with the proposed co-regulation scheme is that, by its connection with the Framework Decision, its scope would be limited to victims in the criminal procedure only - which would exclude stalking victims in certain Member States - and does not apply to the civil or administrative procedure. Article 8 is furthermore limited to protection in the (pre)trial stage. Another alternative, which does not suffer from these limitations, would be the option of open method of coordination (hereafter: OMC). ${ }^{29}$

The OMC is an intergovernmental method which consists of the drafting common guidelines that are to be translated into national policy, combined with periodic monitoring and evaluation processes. Peer reviews are organized and indicators and benchmarks are given

\footnotetext{
${ }^{26}$ Brussels, 20.4.2009, COM (2009) 166 final, report from the Commission pursuant to Article 18 of the Council Framework Decision of 15 March 2001 on the standing of victims in criminal proceedings (2001/220/ JHA) [SEC(22009) 476].

${ }^{27}$ See Rijken, C., \& Letschert, R., Harmonizing legislation in the field of violence against women, violence against children and sexual identity based violence through a human rights based approach: Legal challenges within EU-Law (briefing paper FSL), unpublished.

${ }^{28}$ It is, however, not very likely that this will happen, at least not in the short term. The proposed Directive, which is to replace the current Framework Decision, has restricted its minimum standards to measures to avoid visual contact with the defendant during the trial, to exclusion of the members of the press, and to measures which keep the negative consequences of interviewing victims during the investigative stage to a minimum (Articles 21 and 22 of the European Commission proposal for a Directive of the European Parliament and of the Council establishing minimum standards on the rights, support and protection of victims of crime, COM (2011)275 final).

${ }^{29}$ The open method of coordination was first adopted in the conclusions of the Lisbon Summit in March 2000 (Lisbon European Council (2000): 'Lisbon Extraordinary European Council, 23 and 24 March 2000, Presidency Conclusions', Bulletin of the European Union, No 3.
} 
as means of comparing best practices. The Commission may initiate an $\mathrm{OMC}$ and the $\mathrm{OMC}$ is only applicable to areas which fall within the competence of the Member States. According to the European Commission's feasibility study (2010, pp. 149-150) it is based on:

- Jointly identifying and defining objectives to be achieved (adopted by the Council)

- Jointly established measuring instruments (statistics, indicators, guidelines); and

- Benchmarking, i.e., comparison of the Member States' performance and exchange of best practices (monitored by the Commission).

\section{Conclusion}

If anything, this exercise has certainly shown that there is a pressing need for more reliable information on the actual legal status quo of legal protection orders in the European Member states. Notwithstanding the limitations, the information available does indicate that when it comes to protection orders, there seems to be ample room for improvement. A first thing is to have all Member states implement both civil and criminal restraining orders, since each of them has its own advantages thanks to the differences in the type of legislation they are rooted in and the authority that imposes them. With civil restraining orders, the victim is not dependent on the cooperation of the police, they do not have to be embedded in criminal proceedings, the evidence does not have to meet the criminal law standard, and the entire procedure generally takes up much less time given that they are often provided for in summary proceedings. Furthermore, some victims may shy away from reporting the stalker to the police, because they do not want to stigmatize the offender or because they fear his/her reaction. Disadvantages are that there can be issues with the service of the order on the defendant (Logan et al. 2005), with the enforcement of the order (Logan et al. 2005), and the victim runs the risk of having to pay for the costs of litigation. Ideally, countries have both options at their disposal so that victims can choose which option suits them best. It goes without saying that these member states provide the largest amount of protection to victims.

It is, therefore, obvious that there is plenty of work cut out for the Member States that do not have criminal protection orders at all, but the other Member States cannot rest on their laurels either. Intervention in both the pre-trial and the post-trial stage by the courts, but also by other criminal justice agencies is required. If the scope of providing protection through a criminal protection order is limited to the post-trial stage, then victims run the risk of encountering their harasser in a period during which they are extra vulnerable. Some stalkers become more agitated after they learn that their victim has filed a report with the police, and there have been reports of cases that escalated in the pre-trial stage. Conversely, it does not suffice to merely provide for pre-trial protection either. Since not every stalker is locked away after conviction ${ }^{30}$ and since not every conviction 'cures' the stalker from his or her obsession, there is an enduring need to emphasize the prevailing standard when it comes to interpersonal contact with the victim, if necessary enforced by means of a suspended part of the sentence. Furthermore, access to criminal protection orders should not be limited to the domestic violence context or to relatives and (ex-) partners only. Finally, the EU-wide introduction of the barring order deserves serious consideration as well.

Another interesting development is that in the Scandinavian (Denmark, Finland, Sweden) countries, there appears to be a preference for a separate, administrative or

\footnotetext{
$\overline{{ }^{30} \text { However, an unconditional prison sentence is no guarantee either, since some stalkers have even succeeded }}$ to contact their victims while they were in detention.
} 
quasi-criminal procedure for the administration of protection orders. Typically, these procedures do not require the occurrence of a crime or a link with a criminal procedure and the orders are typically issued by the police or the public prosecutor. What matters is whether a person is in need of protection. The Scandinavian approach is deserving of more academic attention. Is this approach, for example, more effective than the more prevalent approach of pre-trial and post-trial protection orders through criminal procedures? Why is it, for example, that in Finland, where both routes exist, the quasi-criminal approach is far more popular? Which (dis)advantages do both approaches have in comparison to each other?

As for civil restraining orders, they should not only be available, but they should also be accessible to all victims of stalking. Stalking perpetrated by a stranger or an acquaintance can be just as detrimental as ex-intimate stalking and the focus on domestic violence as the main context of stalking - although once very helpful in raising awareness of the problem of stalking and still very helpful in risk assessment - is too limited. ${ }^{31}$ There certainly is a link between stalking and domestic violence, and ex-intimate stalking is probably one of the most likely scenarios that justice authorities will have to deal with, but it is incorrect to interpret stalking exclusively within the realm of domestic violence. Stalking is too heterogeneous a phenomenon to take the domestic violence paradigm as the only principle, thereby risking certain victims to fall under the radar of the civil courts.

If we agree that in the light of today's emphasis on victim protection the current gaps in protection order legislation can no longer be accepted, a strategy needs to be devised on how to solve this problem. At the moment, in many Member States there seems to be a renewed interest in developing new protection order legislation, often in the wake of recently enacted domestic violence or stalking legislation. The trend of paying more attention to safety needs of victims and to developing protection order legislation is a good one which should be further stimulated by the EU. It was argued that the European Union could play an important part in addressing the current vacuum. To begin with, the EU Commission could support a thorough research into the current status of protection order legislation and implementation in the 27 Member States. An accurate study into the different protection order regimes could not only inspire Member States to take action on their own initiative - the outcomes could have a 'naming and shaming' effect - but it would also enable the EU to trace the most prominent gaps in protection and to determine the basic level of protection that Member States should at least be able to offer their victims. After this assessment, careful consideration should be given to which strategy could best enhance the situation. Given the modest competences of the EU in the field of cooperation in criminal, civil and administrative matters, the best approach could be to further explore the options of co-regulation or the open method of coordination.

Open Access This article is distributed under the terms of the Creative Commons Attribution Noncommercial License which permits any noncommercial use, distribution, and reproduction in any medium, provided the original author(s) and source are credited.

\footnotetext{
${ }^{31}$ It is important to acknowledge that many studies have shown that stalking of female victims by male exintimates is the most prevalent form of stalking and that ex-intimate stalkers are generally more persistent and violent than other stalkers (e.g., Tjaden and Thoennes 1998; Pathé and Mullen 1997; Logan et al. 2009). However, the range of both victims and offenders is much wider. Not all violent partners employ stalking tactics after the relationship, not every intimate relationship that turns sour afterward was violent before the break-up, and there are ample examples of very severe stalking cases in which there was no prior romantic involvement at all.
} 


\section{Appendix}

Table 1 Overview of the presence of protection order legislation in the $27 \mathrm{EU}$ Member States based on the five studies

\begin{tabular}{|c|c|c|c|}
\hline Member state & Criminal protection order & Civil protection order & Barring order \\
\hline Austria & $\begin{array}{l}\text { Yes } \\
\text { - yes }(B \& H, A a) \\
\text { - no }(E C) \\
\text { - unclear }(E P O) / \text { no info }(M)\end{array}$ & $\begin{array}{l}\text { Yes } \\
(E P O, M, E C, A a, B \& H)\end{array}$ & $\begin{array}{l}\text { Yes } \\
(E C)\end{array}$ \\
\hline Belgium & $\begin{array}{l}\text { Yes } \\
\text { - yes (EPO, EC, B\&H, Aa) } \\
\text { - no info }(M)\end{array}$ & $\begin{array}{l}\text { Yes } \\
(E P O, M, E C, A a, B \& H)\end{array}$ & $\begin{array}{l}\text { No } \\
(E C)\end{array}$ \\
\hline Bulgaria & $\begin{array}{l}\text { Yes } \\
\text { - yes }(E P O, A a) \\
\text { - no info }(E C)\end{array}$ & $\begin{array}{l}\text { Yes, but only DV } \\
\text { - yes, but only DV (EC, EPO) } \\
\text { - no (Aa) }\end{array}$ & $\begin{array}{l}\text { No } \\
(E C)\end{array}$ \\
\hline Cyprus & $\begin{array}{l}\text { Yes, but only DV and trafficking } \\
\text { - yes (Aa) } \\
\text { - yes, but only } D V(M, B \& H, E C)\end{array}$ & $\begin{array}{l}\text { Yes } \\
\text { - yes }(A a, B \& H) \\
\text {-no info }(E C) \text { /unclear }(M)\end{array}$ & $\begin{array}{l}\text { No } \\
(E C)\end{array}$ \\
\hline Czech Republic & $\begin{array}{l}\text { Yes } \\
\text { - yes }(E P O, M, A a) \\
\text { - no info }(E C)\end{array}$ & $\begin{array}{l}\text { Yes } \\
\text { - yes }(E P O, E C, A a) \\
\text { - no info }(M)\end{array}$ & $\begin{array}{l}\text { Yes } \\
(E C)\end{array}$ \\
\hline Denmark & $\begin{array}{l}\text { Yes, police caution } \\
\text { - yes }(B \& H, A a) \\
\text { - yes, by the police (EPO,EC,M) }\end{array}$ & $\begin{array}{l}\text { Unclear } \\
\text { - yes }(B \& H) \\
\text { - no (Aa) } \\
\text { - no info (EPO, EC, M) }\end{array}$ & $\begin{array}{l}\text { Yes } \\
(E C)\end{array}$ \\
\hline Estonia & $\begin{array}{l}\text { Yes } \\
\text { - yes (EPO, EC) } \\
\text { - no }(A a) \\
\text { - no info }(M)\end{array}$ & $\begin{array}{l}\text { Yes } \\
(E P O, E C, A a, M)\end{array}$ & $\begin{array}{l}\text { No } \\
(E C)\end{array}$ \\
\hline Finland & $\begin{array}{l}\text { Yes } \\
\text { - yes (EPO, M, Aa) } \\
\text { - quasi-criminal/civil (EC) }\end{array}$ & $\begin{array}{l}\text { No, but quasi-civil procedure } \\
\text { - yes (EPO) } \\
\text { - no, quasi-criminal/civil (EC) } \\
\text { - no (Aa) } \\
\text { - no info (M) }\end{array}$ & $\begin{array}{l}\text { Yes } \\
(E C)\end{array}$ \\
\hline France & $\begin{array}{l}\text { Yes } \\
\text { - yes }(E P O, B \& H) \\
\text { - no info }(M, E C)\end{array}$ & $\begin{array}{l}\text { Unclear } \\
\text { - yes (B\&H) } \\
\text { - no (EPO) } \\
\text { - no info (EC) } \\
\text { - unclear (possibly only in case } \\
\text { of DV plus divorce) (M) }\end{array}$ & $\begin{array}{l}\text { No } \\
(E C)\end{array}$ \\
\hline Germany & $\begin{array}{l}\text { Yes } \\
\text { - yes (EPO, EC, } A a, B \& H) \\
\text { - no info (M) }\end{array}$ & $\begin{array}{l}\text { Yes } \\
\text { - yes (B\&H, EPO, EC, Aa, M) }\end{array}$ & $\begin{array}{l}\text { Yes } \\
(E C)\end{array}$ \\
\hline Greece & $\begin{array}{l}\text { Yes } \\
\text { - yes }(A a, B \& H, E C) \\
\text { - no info }(M)\end{array}$ & $\begin{array}{l}\text { Yes } \\
\text { - yes }(B \& H, E C, A a, M)\end{array}$ & $\begin{array}{l}\text { No } \\
(E C)\end{array}$ \\
\hline
\end{tabular}


Table 1 (continued)

\begin{tabular}{|c|c|c|c|}
\hline Member state & Criminal protection order & Civil protection order & Barring order \\
\hline \multirow[t]{3}{*}{ Hungary } & Yes & $\begin{array}{l}\text { Yes, but only (ex)partners } \\
\text { and relatives }\end{array}$ & Yes \\
\hline & - yes $(A a, M)$ & $\begin{array}{l}\text { - yes, but only (ex)partners } \\
\text { and relatives (EC) }\end{array}$ & $(E C)$ \\
\hline & $\begin{array}{l}\text { - yes, but only (ex)partners } \\
\text { and relatives (EC) }\end{array}$ & $\begin{array}{l}\text { - no }(A a) \\
\text { - no info }(M)\end{array}$ & \\
\hline Ireland & $\begin{array}{l}\text { Yes } \\
\text { - yes }(M, A a, E C, B \& H)\end{array}$ & $\begin{array}{l}\text { Yes } \\
\text { - yes }(B \& H, E C, M) \\
\text { - no (Aa) }\end{array}$ & $\begin{array}{l}\text { Yes } \\
(E C)\end{array}$ \\
\hline Italy & $\begin{array}{l}\text { Yes } \\
\text {-yes (EPO, } A a, B \& H, E C) \\
\text { - no (M) }\end{array}$ & $\begin{array}{l}\text { Yes } \\
\text { - yes (B\&H, } A a, E C) \\
\text { - yes, but only in } D V(M) \\
\text { - no (EPO) }\end{array}$ & $\begin{array}{l}\text { No } \\
(E C)\end{array}$ \\
\hline Latvia & $\begin{array}{l}\text { Yes } \\
\text { - yes }(E P O, E C, A a) \\
\text { - no info }(M)\end{array}$ & $\begin{array}{l}\text { No } \\
\text { - no }(E P O, A a, E C) \\
\text { - no info }(M)\end{array}$ & $\begin{array}{l}\text { No } \\
(E C)\end{array}$ \\
\hline Lithuania & $\begin{array}{l}\text { Yes } \\
\text { - yes }(E P O, A a) \\
\text { - yes in cases of } D V(E C)\end{array}$ & $\begin{array}{l}\text { Yes, but only DV } \\
\text { - yes (Aa) } \\
\text { - yes, but only in cases of } \\
D V \text { which lead to a divorce + } \\
\text { only valid until court ruling } \\
\text { (EC, EPO) }\end{array}$ & $\begin{array}{l}\text { No } \\
(E C)\end{array}$ \\
\hline & - no info $(M)$ & - no info $(M)$ & \\
\hline Luxemburg & $\begin{array}{l}\text { Yes } \\
\text { - yes }(M, A a, B \& H) \\
\text { - no }(E C)\end{array}$ & $\begin{array}{l}\text { Yes } \\
\text { - yes }(B \& H, A a, M) \\
\text { - yes, but only after expulsion } \\
\text { from the home (EC) }\end{array}$ & $\begin{array}{l}\text { Yes } \\
(E C)\end{array}$ \\
\hline Malta & $\begin{array}{l}\text { Yes } \\
\text { - yes }(A a, M, E C, B \& H)\end{array}$ & $\begin{array}{l}\text { Yes } \\
\text { - yes }(B \& H, M) \\
\text { - yes, but only in divorce (EC) } \\
\text { - no (Aa) }\end{array}$ & $\begin{array}{l}\text { No } \\
(E C)\end{array}$ \\
\hline The Netherlands & $\begin{array}{l}\text { Yes } \\
\text { - yes (EPO, EC, } A a, B \& H) \\
\text { - no info }(M)\end{array}$ & $\begin{array}{l}\text { Yes } \\
\text { - yes (EPO, EC, } A a, B \& H, M)\end{array}$ & $\begin{array}{l}\text { Yes } \\
(E C)\end{array}$ \\
\hline Poland & $\begin{array}{l}\text { Yes } \\
\text { - yes (EPO, Aa, EC) } \\
\text { - no info }(M)\end{array}$ & $\begin{array}{l}\text { Unclear } \\
\text { - yes }(M) \\
\text { - no, but will be introduced } \\
\text { shortly by amendment (EC) } \\
\text { - no }(E P O, A a)\end{array}$ & $\begin{array}{l}\text { No } \\
(E C)\end{array}$ \\
\hline Portugal & $\begin{array}{l}\text { Yes } \\
\text { - yes (EPO, B\&H, Aa) } \\
\text { - yes, but only DV and } \\
\text { violence }(M) \\
\text { - no info (EC) }\end{array}$ & $\begin{array}{l}\text { No } \\
\text { - yes }(B \& H) \\
\text { - no }(E P O, A a, M) \\
\text { - no info (EC) }\end{array}$ & $\begin{array}{l}\text { No } \\
(E C)\end{array}$ \\
\hline Romania & $\begin{array}{l}\text { No } \\
- \text { no }(E C)\end{array}$ & $\begin{array}{l}\text { No } \\
\text { - no (EC) }\end{array}$ & $\begin{array}{l}\text { No } \\
(E C)\end{array}$ \\
\hline
\end{tabular}


Table 1 (continued)

\begin{tabular}{|c|c|c|c|}
\hline Member state & Criminal protection order & Civil protection order & Barring order \\
\hline Slovakia & $\begin{array}{l}\text { Yes } \\
\text { - yes }(E P O, A a, E C) \\
\text { - no info }(M)\end{array}$ & $\begin{array}{l}\text { Yes } \\
\text { - yes }(E P O, M, E C) \\
\text { - no (Aa) }\end{array}$ & $\begin{array}{l}\text { Yes } \\
(E C)\end{array}$ \\
\hline Slovenia & $\begin{array}{l}\text { Yes } \\
\text { - yes (EPO, EC, Aa, M) }\end{array}$ & $\begin{array}{l}\text { Yes, but only DV } \\
\text { - yes, but only DV between } \\
\text { spouses (EC) } \\
\text { - no (Aa) } \\
\text { - unclear (EPO), no info (M) }\end{array}$ & $\begin{array}{l}\text { Yes } \\
(E C)\end{array}$ \\
\hline Spain & $\begin{array}{l}\text { Yes } \\
\text { - yes }(E P O, A a, B \& H, E C, M)\end{array}$ & $\begin{array}{l}\text { No } \\
\text { - yes }(B \& H) \\
\text { - no }(E P O, E C, A a) \\
\text { - no info }(M)\end{array}$ & $\begin{array}{l}\text { No } \\
(E C)\end{array}$ \\
\hline Sweden & $\begin{array}{l}\text { No, but separate } \\
\text { administrative procedure } \\
\text { - yes }(A a) \\
\text { - no, separate administrative } \\
\text { procedure administered } \\
\text { by public prosecutor } \\
\text { (EPO, B\&H, EC, M) }\end{array}$ & $\begin{array}{l}\text { No, but separate } \\
\text { administrative procedure } \\
\text { - yes }(B \& H) \\
\text { - no }(A a) \\
\text { - no info }(E P O, M, E C)\end{array}$ & $\begin{array}{l}\text { No } \\
(E C)\end{array}$ \\
\hline United Kingdom & $\begin{array}{l}\text { Yes } \\
\text { - yes }(B \& H, A a, E P O, E C, M)\end{array}$ & $\begin{array}{l}\text { Yes } \\
\text { - yes }(B \& H, A a, E P O, E C, M)\end{array}$ & $\begin{array}{l}\text { No } \\
(E C)\end{array}$ \\
\hline
\end{tabular}

$\mathrm{B} \& \mathrm{H}=$ Brienen and Hoegen (2000)

$\mathrm{EPO}=\mathrm{EPO}$ questionnaire

$\mathrm{M}=$ Modena Group on Stalking (2007)

$\mathrm{Aa}=$ Van der Aa et al. (2009)

EC $=$ European Commission's Feasibility Study (2010)

$\mathrm{DV}=$ domestic violence

\section{References}

Brienen, M. E. I., \& Hoegen, E. H. (2000). Victims of crime in 22 European criminal justice systems (diss.). Nijmegen: Wolf Legal Publishers.

Cupach, W. R., \& Spitzberg, B. H. (2004). The dark side of relationship pursuit. From attraction to obsession and stalking. Mahwah, NJ: Lawrence Erlbaum Associates.

European Commission (2009). Report from the Commission pursuant to Article 18 of the council Framework Decision of 15 March 2001 on the standing of victims in criminal proceedings. (COM (2009) 166 final). Brussels: European Commission.

European Commission (2010). Feasibility study to assess the possibilities, opportunities and needs to standardise national legislation on violence against women, violence against children and sexual orientation violence. Luxembourg: Publications Office of the European Union.

European Council (2000). Presidency Conclusions - Lisbon European Council, 23-24 March 2000 (No. 100/ 1/100): European Council.

European Council (2005). The Hague Programme: Strengthening freedom, security and justice in the European union. (OJ/C53/1).

Häkkänen, H., Hagelstam, C., \& Santtila, P. (2003). Stalking actions, prior offender-victim relationships and issuing of restraining orders in a Finnish sample of stalkers. Legal and Criminological Psychology, 8, 189-206.

Hes, J., \& Van Ringen, K. (1986). Blijf uit mijn buurt. Het straatverbod in kort geding: Achtergronden en rechtspraktijk. Den Haag: VUGA. 
Johnson, H., Ollus, N., \& Nevala, S. (2008). Violence against women: An international perspective. New York: Springer.

Keilitz, S. L., Davis, C., Efkeman, H. S., Flango, C., \& Hannaford, P. L. (1998). Civil protection orders: Victims' views on effectiveness. Washington, DC: U.S. Department of Justice.

Logan, T. K., Shannon, L., \& Walker, R. (2005). Protection orders in rural and urban areas: A multiple perspective study. Violence Against Women, 11(7), 876-911.

Logan, T. K., Walker, R., Hoyt, W., \& Faragher, T. (2009). The Kentucky civil protective order study: A rural and urban multiple perspective study of protective order violation consequences, responses, and costs. Kentucky: University of Kentucky.

Malsch, M. (2004). De Wet Belaging: Totstandkoming en toepassing. Nijmegen: Ars Aequi Libri.

Malsch, M., \& Smeenk, W. (2005). Legislation on family violence and stalking. In W. Smeenk \& M. Malsch (Eds.), Family violence and police response: Learning from research, policy and practice in European countries (pp. 223-240). Hampshire: Ashgate.

Meyersfeld, B. (2010). Domestic violence and international law. Oxford: Hart.

Modena Group on Stalking (2007). Protecting women from the new crime of stalking: A comparison of legislative approaches within the European Union. Modena:University of Modena and Reggio Emilia.

Pathé, M., \& Mullen, P. E. (1997). The impact of stalkers on their victims. The British Journal of Psychiatry, 170, 170-172.

Purcell, R., Pathé, M., \& Mullen, P. E. (2005). The association between stalking victimization and psychiatric morbidity in a random community sample. The British Journal of Psychiatry, 187, 416-420.

Sack, E. J. (2004). Domestic violence across state lines: The Full Faith and Credit Clause, Congressional power, and interstate enforcement of protection orders. http://ssrn.com/abstract=838884. Accessed 12 May 2011.

Smith, J. A. (2005). Battered non-wives and unequal protection-order coverage: A call for reform. Yale Law and Policy Review, 23, 93-161.

Stubbs, J. (2008). Domestic violence and women's safety: Feminist challenges to restorative justice, Legal Studies Research Paper No 08/16. http://ssrn.com/abstract =1084680. Accessed 12 May 2011.

Tjaden, P., \& Thoennes, N. (1998). Stalking in America: Findings from the National Violence Against Women Survey. Washington D.C: U.S. Department of Justice, Institute of Justice.

Van der Aa, S. (2010). Stalking in the Netherlands: Nature and prevalence of the problem and the effectiveness of anti-stalking measures (diss.). Apeldoorn: Maklu.

Van der Aa, S., \& Ouwerkerk, J. (2011). The European Protection Order: No time to waste or a waste of time? European Journal of Crime, Criminal Law and Criminal Justice, 19, 267-287.

Van der Aa, S., Van Merriënboer, R., Pemberton, A., Lázaro, J., Rasquete, C., Amaral, C., et al. (2009). Project Victims in Europe: Implementation of the EU Framework Decision on the standing of victims in the criminal proceedings in the Member states of the European Union. Lisbon: APAV.

Vogt, T., \& Greeff, A. P. (2010). The impact of an Interim Protection Order (Domestic Violence Act 116 of 1998) on the victims of domestic violence. Families in Society: The Journal of Contemporary Social Services, 91, 45-51. 